\title{
miRNA Expression Profiles in Luminal A Breast Cancer-Implications in Biology, Prognosis, and Prediction of Response to Hormonal Treatment
}

\author{
Erik Kudela ${ }^{1, *}$, Marek Samec ${ }^{1}$, Lenka Koklesova ${ }^{1}$, Alena Liskova ${ }^{1}$, Peter Kubatka ${ }^{2}$ (D), \\ Erik Kozubik ${ }^{1}$, Tomas Rokos ${ }^{1}$, Terezia Pribulova ${ }^{1}$, Eva Gabonova ${ }^{3}$, Marek Smolar ${ }^{3}$ \\ and Kamil Biringer ${ }^{1}$ \\ 1 Department of Obstetrics and Gynecology, Martin University Hospital and Jessenius Faculty of Medicine in \\ Martin, Comenius University of Bratislava, 03601 Martin, Slovakia; marek.samec@uniba.sk (M.S.); \\ koklesova.lenka@gmail.com (L.K.); liskova80@uniba.sk (A.L.); erik.kozubik@gmail.com (E.K.); \\ rokos1@uniba.sk (T.R.); pribulova.terezia@gmail.com (T.P.); kamil.birnger@uniba.sk (K.B.) \\ 2 Department of Medical Biology, Jessenius Faculty of Medicine, Comenius University in Bratislava, \\ 03601 Martin, Slovakia; peter.kubatka@uniba.sk \\ 3 Clinic of Surgery and Transplant Center, Jessenius Faculty of Medicine in Martin, Comenius \\ University in Bratislava, 03601 Martin, Slovakia; egabonova@gmail.com (E.G.); \\ marino.smolar@gmail.com (M.S.) \\ * Correspondence: erik.kudela@uniba.sk; Tel.: +421-9-0230-0017
}

Received: 18 August 2020; Accepted: 15 October 2020; Published: 17 October 2020

\begin{abstract}
Breast cancer, which is the most common malignancy in women, does not form a uniform nosological unit but represents a group of malignant diseases with specific clinical, histopathological, and molecular characteristics. The increasing knowledge of the complex pathophysiological web of processes connected with breast cancercarcinogenesis allows the development of predictive and prognostic gene expressionand molecular classification systems with improved risk assessment, which could be used for individualized treatment. In our review article, we present the up-to-date knowledge about the role of miRNAs and their prognostic and predictive value in luminal A breast cancer. Indeed, an altered expression profile of miRNAs can distinguish not only between cancer and healthy samples, but they can classify specific molecular subtypes of breast cancer including HER2, Luminal A, Luminal B, and TNBC. Early identification and classification of breast cancer subtypes using miRNA expression profilescharacterize a promising approach in the field of personalized medicine. A detection of sensitive and specific biomarkers to distinguish between healthy and early breast cancer patients can be achieved by an evaluation of the different expression of several miRNAs. Consequently, miRNAs represent a potential as good diagnostic, prognostic, predictive, and therapeutic biomarkers for patients with luminal A in the early stage of BC.
\end{abstract}

Keywords: breast cancer; luminal A; estrogen receptor; miRNA; tamoxifen; prognosis

\section{Introduction}

Despite multiple information campaigns and screening programs, the incidence of breast cancer (BC) is extremely high worldwide. It is the most common malignancy in women, except in the East African region, where cervical cancer is on the top [1]. According to the GLOBOCAN 2018 database, 2 million new cases of BC were diagnosed worldwide in 2018, and 626,000 people died, which is the fourth highest mortality after lung, stomach, and liver cancer [2].

$\mathrm{BC}$ does not form a uniform nosological unit but represents a group of malignant diseases with specific clinical, histopathological, and molecular characteristics. Morphological classification based on 
tumor size and grading has long been shown to be insufficient. Currently, molecular analytical methods help us determine the prognostic and predictive factors of cancer. Perou and Sorlie first proposed the terminology of "molecular classification" in BC with a comprehensive study demonstrating differences in gene expression [3]. Routine assessment of tumor immunophenotype includes examination for estrogen receptors (ERs), progesterone receptors (PRs), and human epidermal growth factor receptor 2 (HER2) expression. These are prognostic markers and important predictive factors for hormonal and anti-HER2 targeting therapy.

ER and PR are hormone receptors that stimulate the growth of both normal and neoplastic breasts. Their expression is present in approximately $75 \%$ of all BC. ER/PR-positive tumors are usually low-grade and less aggressive [4]. A small percentage of tumors show only one hormone receptor positivity. These tumors are more aggressive and less sensitive to hormonal therapy compared to ER/PR-positive tumors [5]. Based on the presence of the expression of these receptors examined by immunohistochemistry, $\mathrm{BC}$ can be divided into four basic subtypes that correlate with mRNA intrinsic subtypes-Luminal A (ER+, PR $\geq 20 \%$, HER2-, Ki67 $<20 \%$ ), Luminal B (ER+, PR $<20 \%$ and/or HER2+ and/or Ki67 $\geq 20 \%$ ), HER2 subtype (ER-, PR-, HER2+), basal-like (triple-negative: ER-, PR-, HER2-) [6]. Some authors report a fifth group of tumors called normal-like (ER+, PR+/-, HER2-, Ki67 low). It is a tumor that, in the early stages, expresses genes like normal breast epithelium. However, it is a controversial group that was later described as artificial and is not widely used in common practice [7].

The latest generations of anti-cancer drugs deserve even more detailed molecular stratification that would help also understand the tumor evolution and resistance to therapy. Even in intrinsic molecular subtypes we see substantial variations in tumor biology with basal-like tumors having the greatest diversity [8]. The novel classification based on the somatic copy number alterations stratifies breast tumors into ten integrative cluster subtypes associated with distinct clinical outcome and response to therapy. Six of these integrative cluster groups are represented by ER dominance compared to two groups of intrinsic types with ER positivity (luminal A and B) [9]. A taxonomy should be dynamic, copying the newest research, knowledge, diagnostic and therapeutic modalities. In our article we present the up-to-date knowledge about the role of miRNAs, their prognostic and predictive value in luminal A BC (breast cancer).

\section{DifferentialMicroRNA Expression in Luminal BCSubtypes}

About 21,000 protein-coding genes thathas been characterized in human genome represent less than $2 \%$ of total genome. The rest but the vast majority of human transcriptome is represented by non-coding RNAs consisting of small RNAs, long non-coding RNAs (lncRNAs) and pseudogenes [10]. These RNA transcripts, especially competing endogenous RNAs (ceRNAs) regulate each other at post-transcription level by competing for shared miRNAs. CeRNA networks describe the interplay between the function of protein-coding mRNAs with non-coding RNAs such as miRNA, IncRNA, pseudogenic RNA, and circular RNA [11]. Small non-coding RNAs, including transfer RNAs, miRNAs and small-interfering RNAs, small nuclear RNAs, small nucleolar RNAs, PIWI-interacting RNAs, and transcription initiation RNAs, are associated with different specific function in translation of mRNAs, post-translational RNA silencing, splicing, ribosomal RNA modification, transposon repression, and transcription regulation, respectively [12]. On the other hand, IncRNAs are implicated in various biological processes (from pluripotency to immune response, RNA gene XIST and the role in dosage compensation) but a large number of lncRNAs are not functionally characterized.

Among the all small non-coding RNAs, microRNAs represent a group of evolutionary conserved non-coding RNAs that regulate gene expression via translational repression or mRNA degradation [13]. Since their discovery in 1993, miRNAs are still a growing field of cancer-associated research [14]. The biogenesis of miRNA is a multi-step process regulated by specific enzymes and proteins contributing to miRNA processing (Figure 1) [15]. Single miRNA can target multiple genes anda group of different miRNAs may regulate the same gene. This fact determines the important role of the short RNA 
sequences in almost all biological processes in the cell [16]. Aberrant expression of miRNAs is directly associated with numerous malignancies, including BC. Indeed, an altered expression profile of miRNAs can distinguish not only between cancer and healthy samples, but they can classify specific molecular subtypes of BC including HER2, Luminal A (LumA), Luminal B (LumB), and TNBC [6,17]. Early identification and classification of BC subtypes using miRNA expression profiles characterizea promising approach in the field of personalized medicine [15].

As was mentioned above, LumA represents a molecular subtype with a better prognosis compared to TNBC or HER2 [18]. Immunohistochemical (IHC) characterization of individual molecular subtypesaccording to IHC markersis a fundamental technique for the classification of BC [19-21]. The progress in molecular biology aimed at miRNA expression profiles demonstrates a prospective way to improve BC classification, including better determination of LumA phenotype. Recently, several studies focus on the analysis of differentiation between BC subtypes and specific miRNAs profiles [22-27]. Søkilde et al. investigated intrinsic subtypes using miRNA expression profiles in $186 \mathrm{BC}$ cases. They identified an alteration in miR-99a/let-7c/miR-125b miRNA cluster associated with proliferative signaling including JAK, STAT3, c-Myc, RAS, AKT/mTOR or ETS1. Acquired data indicated an increased level of the analyzed miRNAs in LumA patients compared to LumB [28]. Interestingly, the level of miR-152-3p, which serve as a tumor suppressor regulating BC cells proliferation via PIK3CA, was lower in patients with LumA than in patients with LumB in the study evaluating miRNA expression profile in blood obtained from 106 patients with newly diagnosed BC [29]. Furthermore, an increased level of miR-29c-5p and miR-30a-3p and decreased level of miR-130b-3p, miR-185-5p, miR-362-5p, and 378a-3p were observed in patients with LumA while its clinical value needs to be further evaluated in clinical setting, authors of the study analyzed two datasets consisting of 186 healthy tissues, 18 ductal carcinomas in situ, and 1338 invasive breast carcinomas [30]. Moi et al. focused on the alterations between miRNA expression and molecular subtypes in the cohort of Norwegian women. They analyzed FFPE from 102 cancer and 36 benign samples. The data showed a significantly decreased level of miR-17-5p and miR-20a-5p, demonstrated to play an important role in the invasion and migration of cancer cells via Wnt/ $\beta$-catenin suppression, in the group ofLumA patients [31]. Another study evaluated the relative and absolute expression of certain miRNAs isolated from whole blood samples $(n=38)$. Experimental data from absolute RT-qPCR quantification revealed that a combination of three miRNAs miR-195 (downregulated), miR-145, and miR-486 (upregulated) had the best diagnostic value for patients with LumA. On the other hand, results from relative RT-qPCR quantification detected the upregulation of miR-155 and miR-486 and downregulation of miR-195. Compared to relative quantification, the absolute quantification technique is better to determine the expression level of miRNA isolated from blood (AUC $=0.657$ vs. AUC $=0.875$ ) [32]. In addition, an expression of miR-1290 was decreased in ER ${ }^{\text {high }}$, Ki67 $7^{\text {low }}$ tumors in the study evaluating the correlation of miRNA expression profiles and clinicopathological factors $(n=64)$. Interestingly, in silico analysis revealed that predictive targets of miR-1290 include Bcl-2, FOXA1, MAPT, and NAT1 [33]. In a meta-analysis of independent studies, van Schooneveld et al. defined specific miRNAs for each intrinsic subtype of BC. They identified a higher expression of let-7c, let-7f, and miR-10a associated with LumA [34]. In another study, Iorio et al. evaluated miRNAs expression profile specific for the individual BC molecular subtypes. In the LumA subtype, the results showed miR-191 and miR-26 upregulation, while level miR-206 was reduced [35]. Moreover, Blenkiron et al. analyzed levels of 309 miRNAs in 93 BC samples. They detected nine miRNAs including miR-100, -99a, -130a, -126, -136, $-146 \mathrm{~b}$ (upregulated), and miR-15b, -107, and 103 (downregulated), which can distinguish LumA from LumB [36].

All previously described studies show an association between miRNA expression profile and BC intrinsic subtypes. According to the specific molecular signatures, miRNAs can define individual steps of carcinogenesis, metastasis development, or chemo/radioresistance, and thus predict prognosis for patients with LumA and other molecular subtypes of BC. 


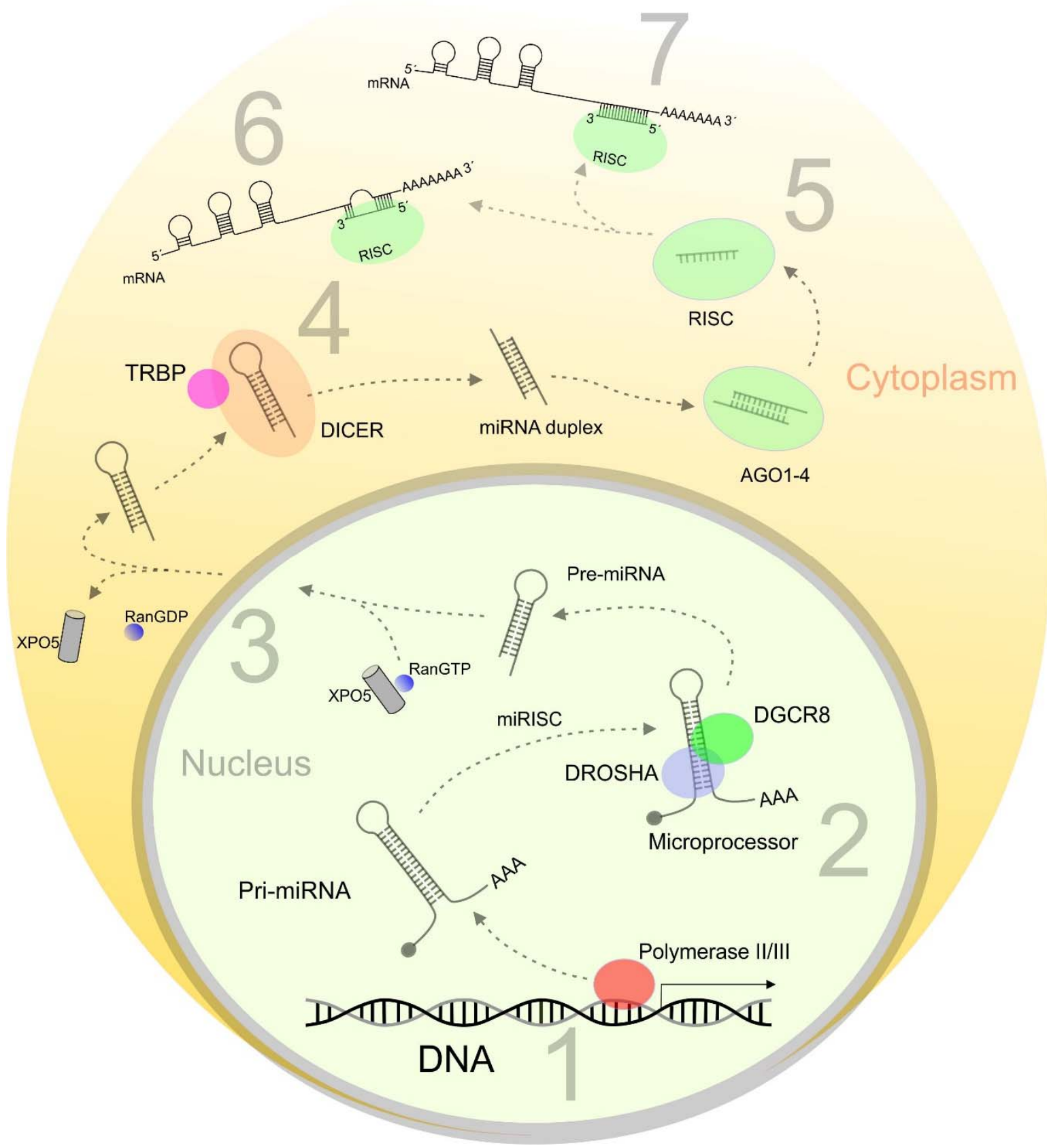

Figure 1. MicroRNA biogenesis. 1: Transcription; 2: Drosha processing; 3: Nuclear export by Exportin-5; 4: Dicer processing; 5: Mature miRNA loaded into RISC; 6: Inhibition of translation; 7: Degradation of targeted mRNA. MicroRNA is transcribed by polymerase II/III as primary miRNA (Pri-miRNA). In the next step, pri-miRNA is cleavaged by the microprocessor (DGCR8 and DROSHA) to generate precursor miRNA (Pre-miRNA) 70nt length. Pre-miRNA is further exported into the cytoplasm by exportin5 (XPO5) and RanGTP. Pre-miRNA is processed into mature miRNA by DICER. One strand of mature miRNA is loaded into the miRNA-induced silencing complex (miRISC). MiRISC consists of Argonaut proteins (AGO) and DICER. MicroRNA in complex with miRISC has effector function by sequence complementarity leading to suppression of translation or degradation of targeted mRNAby binding to the $3^{\prime}$-untranslated regions of mRNA.Pri-miRNA, primary miRNA; DGCR8, DiGeorge syndrome critical region 8; Pre-miRNA, precursor miRNA; XPO5, exportin 5; AGO, argonaut; miRISC, miRNA-induced silencing complex; TRBP, TAR RNA binding protein. 


\section{Specific miRNA Expressionin Early and Metastatic Stage in LumA BC}

$\mathrm{BC}$ appears as a local disease, but later stages can lead to the metastasis to lymph nodes and distant organs [37]. It is important to detect the primary tumor early to prevent the spread of cancer to metastasis.An expression of miRNA in different stages of $\mathrm{BC}$ is variable mainly due to the association of various potential mechanisms [38]. A detection of sensitive and specific biomarkers to distinguish between healthy and early breast cancer (EBC) patients can be achieved by an evaluation of different expression of several miRNAs. Consequently, miRNAs represents potential as good diagnostic, prognostic, predictive, and therapeutic biomarkers for patients with LumA in the early stage of BC [39].

Several studies focused on the differences in miRNAs expression between patients with LumA and healthy controls. Circulating miR-16, miR-21, miR-155, and miR-195 were increased in the serum levels of patients with EBC compared to healthy controls. The same results were observed in serum of patients with LumA compared to healthy controls. Finally, the measurement of the level of circulating miRNAs by BRCA assay, especially the combination of miR-16, miR-21, miR-155, and miR-195, could be used to detect LumA BC [40]. Moreover, the expression of circulating miR-10b, miR-21, miR-145, miR-155, miR-195 was increased in the blood of predominantly early stage and LumA patients compared to healthy controls but only miR-195 expression was specific to the EBC cohort compared to other cancer types and healthy control. An increased sensitivity in the differentiation between BC patients and controls can be attributed to the combination of circulating miRNAs whose expression can be associated with the correlation with disease burden (miR-195) and promotion of cell migration, invasion, and epithelial-mesenchymal transition (EMT) (miR-155) [41].

The reduced expression of miR-181a and miR-652 and unchanged expression of miR-29a was observed in the blood of women with LumA-like BC compared to healthy controls, irrespective of nodal status or stage of disease suggesting that altered expression of miRNAs have an important biomarker characteristic in both early and late stage disease as well as its important role as potential miRNA-related therapeutic strategies [42]. Similarly, the expression of miR-23a-3p and miR-152-3p (negatively regulating PI3KCA expression inhibiting the suppression of BC cell proliferation) revealed lower levels in the blood of patients with LumA, especially in stage I-II, when compared with healthy controls suggesting the potential in early detection of BC [29].

Several comparative studies evaluated miRNAs expression in various patients with BC (age, surgery) the decreased level of circulating miR-338-3p, miR-223, and miR-148a and higher level of miR-107 was observed in post-operative compared to pre-operative samples from post-menopausal women with a molecular characteristic corresponding to LumA including ER+ HER2- EBC. However, the alteration in expression of these miRNAs in the determination of their potential as clinical biomarkers should be validated in larger prospective studies [43].

Study focusing on LumA in vitro revealed an increased expression level of miR-1273g-3p in MCF-7 BC cells compared to normal Hs 578Bst breast cells. Similar data were observed in breast ductal cancer patients compared with healthy donors. Results revealed the potential of miR-1273g-3p, whose increased expression is associated with BC progression by regulating PTEN, as a biomarker for early breast ductal cancer diagnosis [44]. An evaluation of various miRNA levels is important to distinguish the early stage of LumA subtype of BC from non-cancer disease. Different expression of miRNA between EBC patients and healthy controls or other BC stage was revealed in several studies, which are summarized in Table 1 and suggested to be as potential diagnostic, prognostic, predictive, and therapeutic biomarkers.

Circulating miRNAs can be used as markers to identify metastatic disease as was demonstrated by an evaluation of plasma extracted RNA from BC patients that revealed a significant decrease in the expression of miR-195 and an increase in the expression of miR-331, with their molecular roles related to metastatic processes including proliferation, angiogenesis and EMT, in metastasized LumA patients when compared to patients with local disease or healthy controls [45]. 
Table 1. The expression profiles of miRNAs in LumAearly breast cancer (EBC).

\begin{tabular}{|c|c|c|c|}
\hline miRNA & $\begin{array}{l}\text { Patients/Specimen Characteristics } \\
\text { (Number of Patients/Specimens) }\end{array}$ & Results & Reference \\
\hline $\begin{array}{l}\operatorname{miR}-16 \\
\text { miR-21, } \\
\text { miR-155, } \\
\text { miR-195 }\end{array}$ & $\begin{array}{l}\text { Serum from patients with BC }(n=49) \\
\text { and healthy controls }(n=19)\end{array}$ & $\begin{array}{l}\text { Increased level in } \\
\text { LumA EBC }\end{array}$ & [40] \\
\hline miR-195 & $\begin{array}{l}\text { Blood from patients with BC }(n=83) \\
\text { (ductal type-71\%, LumA epithelial } \\
\text { subtype-63\%, early stage-71\%, in situ-12\%) } \\
\text { and healthy controls }(n=63)\end{array}$ & $\begin{array}{l}\text { Higher expression in } \\
\text { EBC patients }\end{array}$ & [41] \\
\hline $\begin{array}{l}\operatorname{miR}-29 a \\
\operatorname{miR}-181 a \\
\operatorname{miR}-652\end{array}$ & $\begin{array}{l}\text { Blood from patients with a new diagnosis of } \\
\text { LumA-like BC }(n=54) \text { and healthy control } \\
\text { participants }(n=56)\end{array}$ & $\begin{array}{l}\text { Reduced expression in } \\
\text { LumA-like BC women }\end{array}$ & [42] \\
\hline $\begin{array}{l}\operatorname{miR}-23 a-3 p \\
\operatorname{miR}-152-3 p\end{array}$ & $\begin{array}{l}\text { Blood samples from patients with } \mathrm{BC}(n=106) \\
(\text { LumA, } n=23) \text { and healthy control }(n=96)\end{array}$ & $\begin{array}{l}\text { Lower level in patients } \\
\text { with LumA }\end{array}$ & [29] \\
\hline $\begin{array}{l}\text { miR-338-3p, } \\
\text { miR-223, } \\
\text { miR-148a }\end{array}$ & $\begin{array}{l}\text { Blood samples before and after surgery of } \\
\text { post-menopausal patients with ER+and } \\
\text { HER2-early stage of BC }(n=24)\end{array}$ & $\begin{array}{l}\text { Lower level in } \\
\text { post-operative ER+ } \\
\text { EBC post-menopausal } \\
\text { women }\end{array}$ & [43] \\
\hline miR-1273g-3p & $\begin{array}{c}\text { MCF-7 BC cells; patients with BC }(n=39) \text { and } \\
\text { healthy controls }(n=40)\end{array}$ & $\begin{array}{l}\text { Increased expression in } \\
\text { MCF-7 cells and BC } \\
\text { patients }\end{array}$ & [44] \\
\hline
\end{tabular}

The association between miRNA pattern and the process of metastasis can be clearly demonstrated by the use of human BC cell lines belonging to the LumA molecular subtype including MCF-7 [46] and T47D [47]. The expression of ER $\alpha$ in LumA metastatic lesions is probably a result of the epithelial differentiation of LumA cancer stem cells upon colonizing a site of metastatic spreading or to the reversion of EMT-generated ER $\alpha$-negative metastatic cells back to ER $\alpha$-positive state during the reverse process of EMT also known as mesenchymal-epithelial transition (MET). Anyway, a relationship between miRNAs targeting ER $\alpha$ has also been examined [48]. ER $\alpha$ was identified as a direct target of miR-203 in MCF-7 cells while the upregulation of miR-203 inhibited estradiol-induced increase in viability, migration and invasion and decreased the protein expression of ER $\alpha$ in MCF-7 cell line [49].

Anoikis is a phenomenon describing apoptotic cell death as a consequence of insufficient cell-matrix interactions [50] and preventing cancer cells from surviving the detachment from the primary tumor site. Nevertheless, in order to become more aggressive and metastatic, cancer cells can develop a resistance to anoikis and undergo changes including EMT [51]. The resistance to anoikis is therefore a hallmark of metastatic cancer cells. MiR-6744-5p was identified to be downregulated in anoikis-resistant sub-cell line (MCF-7-AR6) generated from MCF-7 cells. Moreover, MCF-7-AR6 was also associated with increased migration when compared with MCF-7. However, the overexpression of miR-6744-5p increased while its knockdown decreased the anoikis sensitivity in the MCF-7. Additionally, the overexpression of miR-6744-5p was related to the increased expression of E-cadherin [50], an adhesion molecule whose downregulation facilitates the tumor invasion and metastasis and contributes to the phenotypic appearance of EMT [52]. Furthermore, a xenobiotic metabolizing enzyme- $N$-acetyltransferase 1 (NAT1) - was identified as a direct target of miR-6744-5p. The processes by which NAT1 could contribute to anoikis resistance are not fully clarified yet; however, the possible mechanisms include the DNA damage through chemical carcinogenesis or inhibition of reactive oxygen species to suppress anoikis [50].

Moreover, the attenuation of proliferative, migratory and invasive properties of MCF-7 cells were attributed to the overexpression of miR-765 [53]. In addition, the overexpression of miR-628 increased the migration and invasion of $\mathrm{BC}$ stem cells (BCSCs) in MCF-7 via downregulation of the vimentin and 
Snail expression and upregulation of the E-cadherin expression. miR-628 can potentially suppress the migration and invasion of BCSCs of MCF-7 cells through regulation of its direct target SOS1 [54]. Furthermore, an overexpression of the mitochondrial calcium uniporter (MCU) in MCF-7 cells led to the increase in migration and invasion in vitro and lung metastasis in vivo. Moreover, increased migration and invasion of MCF-7 cells and enhanced glucose uptake was associated with the inhibition of miR-340. Therefore, the ability to regulate BC metastasis via modulation of glycolysis could be attributed to miRNA-340 that targets MCU [55]. Importantly, mammospheres derived from MCF-7 cells represent the model of BCSCs and metastatic tumor tissues with enhanced migration and invasive properties. Importantly, the reduced expression of miR-200c, increased expression of miR-30c as well as increased expression of stem cells markers (OCT4, SOX2, c-MYC) and EMT-related genes (SNAIL1, CDH2, TWIST1/2) was observed in mammospheres, similarly as in case of BC tissues of grade $\mathrm{I} / \mathrm{II}$ patients [56]. Additionally, a downregulation of miR-145-3p-induced metastasis evaluated in MCF-7 cells in which the hypoxia and serum deprivation was used to mimic in vivo cancer microenvironment and trigger metastasis [57].

Besides, the overexpression of miR-520c-3p reduced the invasiveness and migration of both MCF-7 and T47D cells demonstrated via an increased level of E-cadherin and decreased level of vimentin and fibronectin [58]. Similarly, miR-206 overexpression suppressed migration, invasion and EMT of MCF-7 and T47D cells via an inhibition of transforming growth factor beta (TGF- $\beta$ ), neuropilin-1 (NRP1), and SMAD2 [59]. Moreover, the expression of miR-190 was found to be low in BC cell line T47D. Further analysis revealed that overexpression of miR-190 inhibited the process of EMT and angiogenesis [60]. As is shown in Table 2, the evaluation of miRNAs shows a specific pattern of their expression in metastatic $B C$ while the effects of miRNA regulation on processes associated with metastatic spread of LumA BC, such as e.g., anoikis, migration, invasiveness, or EMT, have been demonstrated in in vitro studies conducted on $\mathrm{BC}$ cell lines belonging to the LumA molecular subtype.

Table 2. miRNA pattern in LumA BCassociated with metastasis.

\begin{tabular}{|c|c|c|c|}
\hline miRNA Pattern & Study Design/Model & Result & Ref. \\
\hline $\begin{array}{l}\uparrow \mathrm{miR}-331 \\
\downarrow \mathrm{miR}-195\end{array}$ & $\begin{array}{l}\text { Metastasized BC LumA patients } \\
\text { vs. patients with local disease or } \\
\text { healthy controls }\end{array}$ & & {$[45]$} \\
\hline$\uparrow \mathrm{miR}-203$ & MCF-7 & $\begin{array}{l}\downarrow \text { estradiol-induced viability, migration and invasion } \\
\downarrow \text { ER } \alpha \text { protein expression }\end{array}$ & [49] \\
\hline$\downarrow \mathrm{miR}-6744-5 \mathrm{p}$ & $\begin{array}{l}\text { Anoikis-resistant sub-cell line } \\
\text { (MCF-7-AR6) }\end{array}$ & & {$[50]$} \\
\hline$\uparrow \mathrm{miR}-6744-5 \mathrm{p}$ & \multirow{4}{*}{ MCF-7 } & $\begin{array}{l}\uparrow \text { anoikis sensitivity } \\
\uparrow \text { E-cadherin }\end{array}$ & [50] \\
\hline$\uparrow \mathrm{miR}-765$ & & $\downarrow$ proliferation, migration, invasiveness & {$[53]$} \\
\hline$\uparrow \operatorname{miR}-628$ & & $\begin{array}{l}\uparrow \text { migration, invasiveness } \\
\uparrow \text { E-cadherin } \\
\downarrow \text { vimentin, Snail }\end{array}$ & [54] \\
\hline$\downarrow \mathrm{miR}-340$ & & $\uparrow$ migration, invasiveness & [55] \\
\hline $\begin{array}{l}\downarrow \mathrm{miR}-200 \mathrm{c} \\
\uparrow \mathrm{miR}-30 \mathrm{c}\end{array}$ & MCF-7-derived mammospheres & $\begin{array}{l}\uparrow \text { stem cells markers (OCT4, SOX2, c-MYC) } \\
\uparrow \text { EMT-related genes (SNAIL1, CDH2, TWIST1/2) }\end{array}$ & {$[56]$} \\
\hline$\downarrow \mathrm{miR}-145-3 \mathrm{p}$ & $\begin{array}{l}\text { MCF-7 (metastasisinduced and } \\
\text { cancer environment imitated) }\end{array}$ & & {$[57]$} \\
\hline$\uparrow \mathrm{miR}-520 \mathrm{c}-3 \mathrm{p}$ & \multirow[t]{2}{*}{ MCF-7, T47D } & $\begin{array}{l}\downarrow \text { migration } \\
\uparrow \text { E-cadherin } \\
\downarrow \text { vimentin } \\
\downarrow \text { fibronectin }\end{array}$ & {$[58]$} \\
\hline$\uparrow \mathrm{miR}-206$ & & $\begin{array}{l}\downarrow \text { migration, invasiveness, EMT } \\
\downarrow \text { TGF- } \beta, \text { NRP1, SMAD2 }\end{array}$ & {$[59]$} \\
\hline$\downarrow \mathrm{miR}-190$ & T47D & & {$[60]$} \\
\hline
\end{tabular}


As was discussed above, the expression of miRNAs has been demonstrated to be different among patients with LumA and other molecular subtypes or healthy controls. The expression of specific miRNAs correlates with $B C$ disease burden and isalso associated with various mechanisms related to $\mathrm{BC}$, such as proliferation, promotion of $\mathrm{BC}$ migration, invasiveness, or other processes of $\mathrm{BC}$ progression $[42,43,48]$. Above all, despite that the evaluation of specific miRNA expression represents a potential tool applicable in the differentiation between early and metastatic stage of BC, miRNA expression may be also applicable in the determination of miRNA-regulating therapeutic strategies [42]. The evidence dealing with the evaluation of miRNA expression in the identification of metastatic BC in clinical studies is poor. Nevertheless, the results of preclinical research analyzing the expression of miRNAs in human BC cell lines belonging to LumA molecular subtype revealed that changes in the expression of specific miRNAs arerelated to metastasis-associated mechanisms including changes in migration, invasiveness, EMT or stem cell markers $[49,53,55,57,59]$. Nevertheless, the usefulness of miRNA expression as clinical biomarker need to be evaluated by larger prospective studies [43].

\section{4. miRNAs and BC Prognosis}

Traditional prognostic factors in BC patients include number of positive axillary lymph nodes, tumor size, tumor grade, lymphovascular invasion, and the status of hormonal receptors (ER, PR, and HER2). On the other hand, the development of any kind of cancer involves altered regulation of proliferative and growth-inhibitory pathways, activation of oncogenes and inhibition of tumor-suppressor genes. The increasing knowledge of the complex pathophysiological web of processes connected with $\mathrm{BC}$ development allows the development of predictive and prognostic gene expression and molecular classification systems with improved risk assessment and individualized treatment.

Epigenetic regulation and its use in prognostic and predictive models are modern era phenomenon. miRNAs are a huge group of post-transcriptional regulators that control cellular and developmental processes by targeting messenger RNAs (mRNA). Many of them are significantly upregulated or downregulated in relation to different $\mathrm{BC}$ stages, increased local recurrence risk, and overall survival (Table 3).

Table 3. miRNA associated with worse prognosis, local recurrence, and overall survival.

\begin{tabular}{cccc}
\hline Upregulated miRNA & Reference & Downregulated miRNA & Reference \\
\hline miR-187 & {$[61]$} & miR-203 & {$[49]$} \\
miR-210 & {$[61]$} & miR-182-5p & {$[62]$} \\
miR-224 & {$[61]$} & miR-200b-3p & {$[62]$} \\
miR-9 & {$[61]$} & miR-30b-5p & {$[62]$} \\
miR-1266 & {$[63]$} & miR-30c-5p & {$[62]$} \\
miR-128-3p & {$[64]$} & Let-7 family & {$[65]$} \\
miR-661 & {$[64]$} & miR-891a-5p & {$[64]$} \\
miR-296-3p & {$[64]$} & miR-383-5p & {$[64]$} \\
miR-196a & {$[66]$} & miR-1295a & {$[64]$} \\
\hline
\end{tabular}

Results of a single-miRNA prognostic power are confusing and, in many cases, contradictory. The panel consisting of multiple miRNA might enable a more precise prognostic model and efficient diagnostic tool $[67,68]$. The same principle was used by the authors Zhou et al. who, in a study conducted on two cohorts from The Cancer Genome Atlas (training, $n=596$ and testing set, $n=319$ ) identified miRNA expression profiles model consisting of 14miRNAs that could also serve as potential molecular targets of therapeutic strategies. This model was able to divide patients into high-score and low-score group with different overall survival and also proved the miRNA panel principle [61]. The expression of 71 miRNAs that correlates with prognostic significance was published by the authors Aure et al. [69]. Some of the miRNAs (miR-187, miR-210) may act as independent prognostic markers and their overexpression leads to more aggressive and invasive tumor phenotype [61,70,71]. Moreover, the study conducted on 68 patients with BC revealed the role of miR-9 asa promising predictor of local 
recurrence and lymph node metastases [72,73]. Also, the analysis of $139 \mathrm{BC}$ tissue samples revealed that downregulation of miR-182-5p and miR-200b-3p represents independent prognostic parameter for disease recurrence in patients with luminal BC after endocrine therapy. Decreased disease-free survival is connected with the downregulation of miR-30 family (miR-30b-5p, miR-30c-5p) [62]. On the other hand, a global miRNA screen in primary tumors of 6 matched pairs of ER-positive, postmenopausal BC patients treated with tamoxifen (either recurrence-free or developed a recurrence) suggested that higher expression of miR-126 and miR-10a is seen in patients with longer relapse-free survival. Interestingly, the protective effect of miR-10a is suggested to be associated with the maintenance of the apoptotic capacity of cancer cells while miR-126 could be related to suppression of metastasis and reduction of tumor growth and proliferation [74].

Predictive tools in ER-positive BC like Mammaprint and Oncotype DX are unable to predict recurrence beyond five years [75]. Incorporating other molecular parameters could enhance the available predictive models. One study correlated miRNA expression and Oncotype DX recurrence score (RS). They detected reduced expression of let-7 family and high expression of miR-377-5p, miR-633b and miR-3648were associated with high RS scores [65]. On the contrary, let-7 family members are downregulated in tumors with high recurrence score [43]. What is interesting, not only upregulation or downregulation of miRNAs affect the process of carcinogenesis. Even the increase activity of selected miRNAs like miR-500a is connected with increased BC mortality [76].

There is a possibility to go deeper in the analysis of prognostic effect of particular miRNA. Single nucleotide polymorphisms can change the binding sites of miRNA for mRNA and alter the final effect. The study of Lee et al., conducted on 452 patients with EBC, provided evidence that the miR-196a rs11614913T $>$ C polymorphisms are possible prognostic biomarkers for hormone receptor-positive BC. The patient with the CC genotype showed worse prognosis compared to TT or TC genotype [77].

In conclusion, various miRNAs are related to regulation of various mechanisms connected to carcinogenesis, such as processes of apoptosis, proliferation, tumor growth, or metastasis [74]. Therefore, the analysis of the miRNA expression, especially panels of multiple miRNAs, represents a promising tool enabling the evaluation of $\mathrm{BC}$ prognosis while its prognostic significance has been demonstrated by several authors $[61,67,70]$.

\section{5. miRNAs and Their Role in Endocrine Resistance}

Almost $70 \%$ of BC cases are characterized by estrogen receptor (ER) positivity making these patients eligible for endocrine therapy including selective modulators of estrogen receptors (SERMs), selective estrogen receptor degrader (SERD) fulvestrant, and aromatase inhibitors (AIs). The collaborative meta-analysis of individual patient data with diagnosed EBC $(n=21,457)$ revealed that tamoxifen (TAM) reduces the mortality by $28 \%$ at 15 -years follow-up and is recommended as a first line treatment for premenopausal BC patients. Moreover, PR measurement was not predictive in the respond to tamoxifen therapy. Therefore, the study was limited to ER-positive disease with 10,645 women [78]. The majority of luminal A BC responds well to endocrine therapy, but on the other side $40 \%$ of BC patients develop resistance [79]. This finding explains the fact that luminal A BC have relatively high rates of recurrence and metastases and are among the most threatening types of $B C$ [80]. Endocrine resistance is either primary (when the patients relapse within the first 24 months of endocrine therapy) or secondary (relapse of the BC is diagnosed while the patient is on adjuvant endocrine therapy after 2 years of treatment or within 12 months after completing treatment [81].

Multiple studies have been published evaluating the exact molecular mechanisms of endocrine resistance. These molecular pathways include modification of $E R \alpha$ receptor expression, regulation of signal transduction pathways, altered expression of miRNAs, balance of regulatory proteins, and genetic polymorphisms [82]. In our systematic review, we focused on the already published studies regarding the connection of up/downregulation of miRNA and endocrine therapy resistance.

miRNAs can be both tumor suppressors and oncogenes depending on cellular system. Their expression inversely correlates with their targeted mRNAs. Selected miRNAs are consistently 
upregulated (miR-181-b) with functional targets including HEY1, CA2, PIK3R1, LYN, ESR1, JUN, STAT1, $M Y B, B C L 2, C Y C S, B A M B I, C T G F$, and SOX9 or downregulated (miR-342-3p/5p) with functional targets including FYN, TGFBR1, COL4A6, CDKN1A, and Ephrins EPHA4/7 in all MCF-7/TAM-resistant cell lines. Furthermore, altered expression of miR-190b and miR-516a-5p in TAM-resistant cells revealed the predictive treatment outcome in a cohort of ER+ BC patients with tamoxifen mono-therapy [83]. Single miRNA prediction model of resistance has a low predictive power with different results across the studies. That is why the research is focused on multi miRNA expression profiles and predictive models [25]. Study of Joshi et al. showed alterations in expression of 131 different miRNAs in TAM-resistant cells [83]. What is more, Nam et al. identified undescribed network clusters consisting of miR-146a, miR-27a, miR-145, miR-21, miR-155, miR-15a, miR-125b, let-7s and miR 221/222, which contribute both to TAM and fulvestrant resistance. This "integrative network" focused on joint miRNA-mRNA expression profile, miRNA-target mRNA relationship, miRNA upstream regulators, and cancer context [84]. miR 221/222 cluster is one of the most important regulators of estrogen receptors and have a crucial role in TAM resistance $[85,86]$. Protein p27 representing a predictive factor for tamoxifen therapy response is one of the targets of miR 221/222. P27 is reduced by $28-50 \%$ in miRNA $221 / 222$ overexpressing MCF-7 BC cells. Miller et al. demonstrated that the overexpressed miR-221/222 could be a potential pattern not only of TAM but also fulvestrant resistance. Moreover, the first mention of the relationship between miR-221/222 expression and HER2/neu overexpression was observed in primary BC samples resistant to TAM therapy [85-87].

miRNAs are also very promising novel therapeutic approach to sensitize and suppress the growth of TAM-resistant tumors [88]. Zhang et al.demonstrated downregulatedexpression of miR-135a in $\mathrm{ER} \alpha+\mathrm{BC}$ cells with acquired TAM resistance; however, the overexpression of miR-135a partially resensitized cells to TAM therapy through the activation of ERK1/2 and AKT pathways and miR-135a targeted genes ESR1, ESRRA, and NCOA1 [89]. The same principle was seen in case of miR-27 that increases the levels of ER $\alpha$ [90]. miR-34 could also be an effective target to reverse TAM resistance. The first anti-cancer miRNA drug that mimics miR-34 has now reached first phase of clinical testing in patients withprimary liver cancer. miRNA-based therapeutics could have an important effect on tumor, because a single miRNA could affect multiple therapeutic targets with no side effects [91]. The other target could be miR873/CDK3 complex that also plays a crucial role in ER $\alpha$ signaling and TAM resistance. Norcanthraridin used as an anti-cancer drug in China sensitize resistant cells to TAM through the modulation of miR873 axis with downregulation of CDK3 [92,93]. The other potential therapeutic targets are represented by let-7 family [94], miR-155 [95], miR-192-5p, miR500a-3p and miR-206 [94,96,97]. Differently expressed miRNAs in tamoxifen-resistant and sensitive BC is summarized in Tables 4 and 5.

Table 4. Differently regulated miRNA in tamoxifen-resistant BC.

\begin{tabular}{ccc}
\hline \multicolumn{3}{c}{ Downregulated miRNA in Tamoxifen-Resistant BC } \\
\hline miRNA & Target Gene & Reference \\
\hline miR-106b & $Y W H A G, Y W H A Z$ & {$[83]$} \\
miR-125a-3p & CDK3 & {$[93]$} \\
miR-135a & FOXM1, ERK1/2, AKT1 & {$[83]$} \\
miR-186-3p & $E R E G$ & {$[98]$} \\
miR-26a & $E 2 F 7$ & {$[99]$} \\
miR-27b-3p & NR5A2, CREB1 & {$[100]$} \\
miR-33b & $F Y N$ & {$[83]$} \\
miR-342-3p/5p & $F Y N$ & {$[83]$} \\
miR-378a-3p & $G O L T 1 A$ & {$[101]$} \\
miR-449a & $A D A M 22$ & {$[88]$} \\
miR-491-5p & $Y W H A G, Y W H A Z$ & {$[83]$} \\
miR-577 & $Y W H A G, Y W H A Z$ & {$[83]$} \\
\hline
\end{tabular}


Table 4. Cont.

\begin{tabular}{ccc}
\hline \multicolumn{4}{c}{ Downregulated miRNA in Tamoxifen-Resistant BC } \\
\hline miRNA & Target Gene & Reference \\
\hline miR-593 & SNAI2 & {$[83]$} \\
miR-873 & CDK3 & {$[92]$} \\
miR-942 & $Y W H A G$, YWHAZ & {$[83]$} \\
miR-96 & YWHAG, YWHAZ & {$[83]$} \\
\hline Upregulated miRNA in Tamoxifen-Resistant BC \\
\hline miRNA & Target Gene & Reference \\
\hline miR-10b & $H D A C 4$ & {$[102]$} \\
miR-18a & MYBL2 & {$[103]$} \\
miR-101 & $M A G I 2$, Akt & {$[91]$} \\
miR-155 & SOCS6-STAT3 & {$[95]$} \\
miR-181b & STAT1,MYB, BCL2, SOX9 & {$[83,104]$} \\
miR-192-5p & $E R \alpha$ & {$[96]$} \\
miR-196a & $H o x, F o x, C d k i n h i b$. & {$[66]$} \\
miR-21 & $T I M P 3, A D A M$ & {$[105,106]$} \\
miR-221 & $P 27, E R \alpha$ & {$[107]$} \\
miR-222 & $P 27, E R \alpha$ & {$[107]$} \\
miR-335-5p/3p & & {$[108]$} \\
miR-519a & CDKN1 & {$[109]$} \\
miR-663b & TP73 & {$[110]$} \\
miR-92a-3p & & {$[87]$} \\
\hline & &
\end{tabular}

Table 5. Differently regulated miRNA in tamoxifen sensitive BC.

\begin{tabular}{ccc}
\hline \multicolumn{3}{c}{ Downregulated miRNA in Tamoxifen Sensitive BC } \\
\hline miRNA & Target Gene & Reference \\
\hline miR-301 & PTEN, Akt & {$[111]$} \\
\hline Upregulated miRNA in Tamoxifen Sensitive BC \\
\hline miRNA & Target Gene & Reference \\
\hline miR-148a & $A L C A M$ & {$[112]$} \\
miR-152 & $A L C A M$ & {$[112]$} \\
miR-200b/c & ZEB1 & {$[113,114]$} \\
miR-214 & UCP2 & {$[97]$} \\
miR-261 & $A G R$ & {$[115]$} \\
miR-27a & ZBTB10 & {$[90]$} \\
miR-320a & $A R P P-19$ & {$[93]$} \\
miR-34 & $C C N D 1, C D K 4 / 6$ & {$[116-118]$} \\
miR-375 & $M T D H, Z E B 1, S N A I 2$ & {$[119]$} \\
miR-451 & $H E R, E G F R, M A P K$ & {$[80]$} \\
miR-575 & $A G R$ & {$[115]$} \\
\hline
\end{tabular}

miRNAs may play acritical role also in resistance to fulvestrant (Table 6) that is used as asecond-line therapy in cases of metastatic BC [120]. Acquired fulvestrant resistance is an ER $\alpha$ independent condition with alteration of growth hormone pathways, glycoprotein 88 overexpression [121], and functional methylation of the ER promoter region [120,122]. miR-143, miR-145, miR-137, miR-424, miR-21 may play important roles in fulvestrant resistance as well as miR-221/222, which is upregulated in fulvestrant-resistant cancer cell lines [123-125]. 
Table 6. Differently regulated miRNA in fulvestrant-resistant BC.

\begin{tabular}{ccc}
\hline \multicolumn{3}{c}{ Downregulated miRNA in Fulvestrant-Resistant BC } \\
\hline miRNA & Target Gene & Reference \\
\hline miR-137 & $S R C 3$ & {$[126]$} \\
miR-143 & & {$[126]$} \\
miR-145 & & {$[126]$} \\
miR-424 & PI3K/Akt/mTOR & {$[126]$} \\
\hline Upregulated miRNA in Fulvestrant-Resistant BC \\
\hline miRNA & Target Gene & Reference \\
\hline miR-21 & PI3K/Akt/mTOR & {$[126]$} \\
miR-221 & $P C D H 10$ & {$[126]$} \\
miR-222 & $C A M s ~ K E G G$ pathway & {$[126]$} \\
\hline
\end{tabular}

Aromatase inhibitor (AI) therapy is afirst line treatment in postmenopausal women. The study of Vilquinet al. showed for the first time that the deregulated miRNA expression of miR-23b, miR-484, miR-21, miR-301, and miR-193a activates the AKT pathway and causes the acquisition in AI therapy resistance. Therapeutic blocking of miRNA expression like miR-125b could initiate greater response to AI endocrine therapy [127]. Another pathway of AI resistance is the metabolic reprogramming by miR-155, where the overexpression of selected miRNA is correlated with poor response to AIs [128]. The summary of upregulated miRNAs in AI-resistant BC is shown in Table 7.

Table 7. Differently regulated miRNA in aromatase-resistant BC.

\begin{tabular}{cccc}
\hline \multicolumn{3}{c}{ Upregulated miRNA in Aromatase Inhibitor-Resistant BC } \\
\hline miRNA & Target Gene & Reference & Aromatase inhibitor \\
\hline miR-125b & $A k t / m T O R$ & {$[127]$} & Letrozole, anastrozole \\
miR-128a & TGFbRI & {$[129]$} & Letrozole \\
miR-155 & $H K 2, S T A T 3$ & {$[128]$} & Anastrozole \\
miR-205 & $A k t / m T O R$ & {$[127]$} & Letrozole/anastrozole \\
miR-432-5p & $T G F-\beta$ & {$[130]$} & Letrozole/anastrozole \\
miR-433-3p & $M A P K$ & {$[130]$} & Letrozole/anastrozole \\
\hline
\end{tabular}

CDK4/6 inhibitors like Palbociclib, which are the newest therapy modality, could be used in combination with TAM in resistant BC. One of the markers that is able to indicate effective therapy by CDK inhibitors could be the overexpression of miR-18a, which is related to tumors with higher proliferation index and identifies high-risk luminal BC patients [103]. On the other hand, downregulation of miR-223 confers resistance to CDK 4/6 inhibitors in luminal BC and identifies aggressive DCIS as an early event during mammary carcinogenesis. miR-223 expression is increased in case of palbociclib therapy and is a marker of effective treatment [131].

As was mentioned above, the dysregulation of miRNAshas been considered as a critical mediator of cancer development and progression [89]. Although the anti-cancer drugs are initially effective, the clinical benefits from their use are limited by the development of endocrine resistance. An identification of target genes, protein-protein interactions of deregulated miRNAs and new knowledge about the resistance to anti-cancer drugs can give a base for the development of novel therapeutics targeting specific molecules $[83,88,89]$.

\section{Conclusions}

Luminal A BC is the most common intrinsic type of malignant breast tumors. Despite their favorable prognosis and availability of targeted hormonal therapy, we still need to find new efficient prognostic and predictive markers for individualized approaches and personalized therapy. New studies 
emerging in the last decade show a significant heterogenicity in luminal A BC type [8]. Recent evidence suggests that epigenetic changes including the expression of various miRNAs can distinguish the tumors with worse overall prognosis and different answers to hormonal therapy including tamoxifen, fulvestrant, or aromatase inhibitors. Complex miRNA expression profilesare also a promising target for an advanced therapy of luminal A BC. The heterogeneous nature of malignant diseases requiresmore precise management of individual patients for the purpose of personalized treatment within the concept of precision medicine. The determination of specific levels of expression of different miRNAs or panels of multiple miRNAs enable the identification of valuable BC biomarkers. Recently, a rich evidence has been published on the specific levels of expression of individual miRNAs at settings of BC, which deeply contribute to the significance of the potential use the analysis of epigenetic changes in the management of BC. Despite promising results, the evaluation of the applicability of miRNA expression in the prediction and prognosis of $B C$ has been associated with certain limitations, e.g., the number of enrolled samples and the requirement of larger samples [73]. Also, discrepancies between various studies regarding e.g., the role of specific miRNA evaluated by different authors may be associated with their specific focus, demonstrating that different disease settings and study designs yield different candidates [74]. Regarding the evaluation of the likelihood of recurrence and resistance to therapeutics such as endocrine resistance $[83,88,89]$, the expression of miRNAs should be tested in primary tumor sites, ideally in multicenter studies. Moreover, in vitro evaluation might contribute to the functional characterization of specific miRNAs [62]. Above all, the role of miRNA expression in liquid biopsies highlights its role as a non-invasive biomarker [67]. Nevertheless, overcoming the limitations observed so far in the investigation of the applicability of miRNA expression or panels of multiple miRNAs in the diagnosis or determination of the strategy of $\mathrm{BC}$ treatment is necessary for a better understanding of the role of miRNA within the heterogenous nature of $B C$ required for further progress in the usability of miRNAs in BC management. In conclusion, a personalized approach using the miRNA diagnostics and targeted therapy could lead to a substantial change in BC paradigm, exact estimation of patient prognosis, and overall survival.

Funding: This study was funded by the Scientific Grant Agency of the Ministry of Education of the Slovak Republic under contract no. 1/0124/17, the Slovak Research and Development Agency under contract no. APVV-16-0021, Ministry of Health grant no. 2018/20-UKMT-16 and also by the project Molecular diagnosis of cervical cancer, ITMS: 26220220113 supported by the Operational Programme Research and Innovation funded by the ERDF.

Acknowledgments: Biomedical Center Martin, Jessenius Faculty of Medicine, Comenius University in Bratislava, Slovakia, Grant Agency of the Ministry of Education of the Slovak Republic under contract no. 1/0124/17, the Slovak Research and Development Agency under contract no. APVV-16-0021, Ministry of Health grant no. 2018/20-UKMT-16 and also by the project Molecular diagnosis of cervical cancer, ITMS: 26220220113 supported by the Operational Programme Research and Innovation funded by the ERDF.

Conflicts of Interest: The authors declare no conflict of interest.

\section{References}

1. Ferlay, J.; Colombet, M.; Soerjomataram, I.; Mathers, C.; Parkin, D.M.; Piñeros, M.; Znaor, A.; Bray, F. Estimating the global cancer incidence and mortality in 2018: GLOBOCAN sources and methods. Int. J. Cancer 2019, 144, 1941-1953. [CrossRef] [PubMed]

2. Bray, F.; Ferlay, J.; Soerjomataram, I.; Siegel, R.L.; Torre, L.A.; Jemal, A. Global cancer statistics 2018: GLOBOCAN estimates of incidence and mortality worldwide for 36 cancers in 185 countries. CA Cancer J. Clin. 2018, 68, 394-424. [CrossRef] [PubMed]

3. Perou, C.M.; Sørlie, T.; Eisen, M.B.; van de Rijn, M.; Jeffrey, S.S.; Rees, C.A.; Pollack, J.R.; Ross, D.T.; Johnsen, H.; Akslen, L.A.; et al. Molecular portraits of human breast tumours. Nature 2000, 406, 747-752. [CrossRef] [PubMed]

4. Hammond, M.E.H.; Hayes, D.F.; Dowsett, M.; Allred, D.C.; Hagerty, K.L.; Badve, S.; Fitzgibbons, P.L.; Francis, G.; Goldstein, N.S.; Hayes, M.; et al. American Society of Clinical Oncology/College Of American Pathologists guideline recommendations for immunohistochemical testing of estrogen and progesterone receptors in breast cancer. J. Clin. Oncol. 2010, 28, 2784-2795. [CrossRef] [PubMed] 
5. Ethier, J.L.; Ocaña, A.; Rodríguez Lescure, A.; Ruíz, A.; Alba, E.; Calvo, L.; Ruíz-Borrego, M.; Santaballa, A.; Rodríguez, C.A.; Crespo, C.; et al. Outcomes of single versus double hormone receptor-positive breast cancer. A GEICAM/9906 sub-study. Eur. J. Cancer 2018, 94, 199-205. [CrossRef]

6. Cantini, L.; Bertoli, G.; Cava, C.; Dubois, T.; Zinovyev, A.; Caselle, M.; Castiglioni, I.; Barillot, E.; Martignetti, L. Identification of microRNA clusters cooperatively acting on epithelial to mesenchymal transition in triple negative breast cancer. Nucleic Acids Res. 2019, 47, 2205-2215. [CrossRef]

7. Peppercorn, J.; Perou, C.M.; Carey, L.A. Molecular subtypes in breast cancer evaluation and management: Divide and conquer. Cancer Invest. 2008, 26, 1-10. [CrossRef]

8. Russnes, H.G.; Lingjærde, O.C.; Børresen-Dale, A.-L.; Caldas, C. Breast Cancer Molecular Stratification: From Intrinsic Subtypes to Integrative Clusters. Am. J. Pathol. 2017, 187, 2152-2162. [CrossRef]

9. Curtis, C.; Shah, S.P.; Chin, S.-F.; Turashvili, G.; Rueda, O.M.; Dunning, M.J.; Speed, D.; Lynch, A.G.; Samarajiwa, S.; Yuan, Y.; et al. The genomic and transcriptomic architecture of 2,000 breast tumours reveals novel subgroups. Nature 2012, 486, 346-352. [CrossRef]

10. ENCODE Project Consortium An integrated encyclopedia of DNA elements in the human genome. Nature 2012, 489, 57-74. [CrossRef]

11. Qi, X.; Zhang, D.-H.; Wu, N.; Xiao, J.-H.; Wang, X.; Ma, W. ceRNA in cancer: Possible functions and clinical implications. J. Med. Genet. 2015, 52, 710-718. [CrossRef] [PubMed]

12. Tay, Y.; Rinn, J.; Pandolfi, P.P. The multilayered complexity of ceRNA crosstalk and competition. Nature 2014, 505, 344-352. [CrossRef] [PubMed]

13. Rizzuti, M.; Filosa, G.; Melzi, V.; Calandriello, L.; Dioni, L.; Bollati, V.; Bresolin, N.; Comi, G.P.; Barabino, S.; Nizzardo, M.; et al. MicroRNA expression analysis identifies a subset of downregulated miRNAs in ALS motor neuron progenitors. Sci. Rep. 2018, 8, 1-12. [CrossRef] [PubMed]

14. Paul, J.; Muthuswami, R. MicroRNA: Perspectives in Health and Diseases; CRC Press: Boca Raton, FL, USA, 2018.

15. Zubor, P.; Kubatka, P.; Dankova, Z.; Gondova, A.; Kajo, K.; Hatok, J.; Samec, M.; Jagelkova, M.; Krivus, S.; Holubekova, V.; et al. miRNA in a multiomic context for diagnosis, treatment monitoring and personalized management of metastatic breast cancer. Future Oncol. 2018, 14, 1847-1867. [CrossRef] [PubMed]

16. Jevšinek Skok, D.; Hauptman, N.; Boštjančič, E.; Zidar, N. The integrative knowledge base for miRNA-mRNA expression in colorectal cancer. Sci. Rep. 2019, 9, 1-9. [CrossRef]

17. Al-thoubaity, F.K. Molecular classification of breast cancer: A retrospective cohort study. Ann. Med. Surg. 2020, 49, 44-48. [CrossRef]

18. Kudela, E.; Samec, M.; Kubatka, P.; Nachajova, M.; Laucekova, Z.; Liskova, A.; Dokus, K.; Biringer, K.; Simova, D.; Gabonova, E.; et al. Breast Cancer in Young Women: Status Quo and Advanced Disease Management by a Predictive, Preventive, and Personalized Approach. Cancers 2019, 11, 1791. [CrossRef]

19. Fragomeni, S.M.; Sciallis, A.; Jeruss, J.S. Molecular subtypes and local-regional control of breast cancer. Surg. Oncol. Clin. N. Am. 2018, 27, 95-120. [CrossRef]

20. Dai, X.; Xiang, L.; Li, T.; Bai, Z. Cancer Hallmarks, Biomarkers and Breast Cancer Molecular Subtypes. J. Cancer 2016, 7, 1281-1294. [CrossRef]

21. Tang, P.; Tse, G.M. Immunohistochemical Surrogates for Molecular Classification of Breast Carcinoma: A 2015 Update. Arch. Pathol. Lab. Med. 2016, 140, 806-814. [CrossRef]

22. Jin, C.; Yan, B.; Lu, Q.; Lin, Y.; Ma, L. Reciprocal regulation of Hsa-miR-1 and long noncoding RNA MALAT1 promotes triple-negative breast cancer development. Tumour Biol. 2016, 37, 7383-7394. [CrossRef] [PubMed]

23. Crippa, E.; Lusa, L.; De Cecco, L.; Marchesi, E.; Calin, G.A.; Radice, P.; Manoukian, S.; Peissel, B.; Daidone, M.G.; Gariboldi, M.; et al. miR-342 regulates BRCA1 expression through modulation of ID4 in breast cancer. PLoS ONE 2014, 9, e87039. [CrossRef] [PubMed]

24. Shin, V.Y.; Kwong, A. Response to: Comment on "Circulating cell-free miRNAs as biomarker for triple-negative breast cancer". Br. J. Cancer 2016, 114, e6. [CrossRef] [PubMed]

25. Braicu, C.; Raduly, L.; Morar-Bolba, G.; Cojocneanu, R.; Jurj, A.; Pop, L.-A.; Pileczki, V.; Ciocan, C.; Moldovan, A.; Irimie, A.; et al. Aberrant miRNAs expressed in HER-2 negative breast cancers patient. J. Exp. Clin. Cancer Res. 2018, 37, 257. [CrossRef]

26. Bai, X.; Han, G.; Liu, Y.; Jiang, H.; He, Q. miRNA-20a-5p promotes the growth of triple-negative breast cancer cells through targeting RUNX3. Biomed. Pharmacother. 2018, 103, 1482-1489. [CrossRef] 
27. Savad, S.; Mehdipour, P.; Miryounesi, M.; Shirkoohi, R.; Fereidooni, F.; Mansouri, F.; Modarressi, M.H. Expression analysis of MiR-21, MiR-205, and MiR-342 in breast cancer in Iran. Asian Pac. J. Cancer Prev. 2012, 13, 873-877. [CrossRef]

28. Søkilde, R.; Persson, H.; Ehinger, A.; Pirona, A.C.; Fernö, M.; Hegardt, C.; Larsson, C.; Loman, N.; Malmberg, M.; Rydén, L.; et al. Refinement of breast cancer molecular classification by miRNA expression profiles. BMC Genom. 2019, 20, 503. [CrossRef]

29. Li, X.; Zou, W.; Wang, Y.; Liao, Z.; Li, L.; Zhai, Y.; Zhang, L.; Gu, S.; Zhao, X. Plasma-based microRNA signatures in early diagnosis of breast cancer. Mol. Genet. Genomic Med. 2020, 8. [CrossRef]

30. Haakensen, V.D.; Nygaard, V.; Greger, L.; Aure, M.R.; Fromm, B.; Bukholm, I.R.K.; Lüders, T.; Chin, S.-F.; Git, A.; Caldas, C.; et al. Subtype-specific micro-RNA expression signatures in breast cancer progression. Int. J. Cancer 2016, 139, 1117-1128. [CrossRef]

31. Moi, L.; Braaten, T.; Al-Shibli, K.; Lund, E.; Busund, L.-T.R. Differential expression of the miR-17-92 cluster and miR-17 family in breast cancer according to tumor type; results from the Norwegian Women and Cancer (NOWAC) study. J. Transl. Med. 2019, 17,334. [CrossRef]

32. Arabkari, V.; Clancy, E.; Dwyer, R.M.; Kerin, M.J.; Kalinina, O.; Holian, E.; Newell, J.; Smith, T.J. Relative and Absolute Expression Analysis of MicroRNAs Associated with Luminal A Breast Cancer- A Comparison. Pathol. Oncol. Res. 2019. [CrossRef] [PubMed]

33. Endo, Y.; Toyama, T.; Takahashi, S.; Yoshimoto, N.; Iwasa, M.; Asano, T.; Fujii, Y.; Yamashita, H. miR-1290 and its potential targets are associated with characteristics of estrogen receptor $\alpha$-positive breast cancer. Endocr. Relat. Cancer 2013, 20, 91-102. [CrossRef]

34. Van Schooneveld, E.; Wildiers, H.; Vergote, I.; Vermeulen, P.B.; Dirix, L.Y.; Van Laere, S.J. Dysregulation of microRNAs in breast cancer and their potential role as prognostic and predictive biomarkers in patient management. Breast Cancer Res. 2015, 17. [CrossRef]

35. Iorio, M.V.; Ferracin, M.; Liu, C.-G.; Veronese, A.; Spizzo, R.; Sabbioni, S.; Magri, E.; Pedriali, M.; Fabbri, M.; Campiglio, M.; et al. MicroRNA Gene Expression Deregulation in Human Breast Cancer. Cancer Res. 2005, 65, 7065-7070. [CrossRef]

36. Blenkiron, C.; Goldstein, L.D.; Thorne, N.P.; Spiteri, I.; Chin, S.-F.; Dunning, M.J.; Barbosa-Morais, N.L.; Teschendorff, A.E.; Green, A.R.; Ellis, I.O.; et al. MicroRNA expression profiling of human breast cancer identifies new markers of tumor subtype. Genome Biol. 2007, 8, R214. [CrossRef]

37. Weigelt, B.; Peterse, J.L.; van 't Veer, L.J. Breast cancer metastasis: Markers and models. Nat. Rev. Cancer 2005, 5, 591-602. [CrossRef] [PubMed]

38. Calin, G.A.; Croce, C.M. MicroRNA signatures in human cancers. Nat. Rev. Cancer 2006, 6, 857-866. [CrossRef] [PubMed]

39. Nassar, F.J.; Nasr, R.; Talhouk, R. MicroRNAs as biomarkers for early breast cancer diagnosis, prognosis and therapy prediction. Pharmacol. Ther. 2017, 172, 34-49. [CrossRef]

40. Fan, T.; Mao, Y.; Sun, Q.; Liu, F.; Lin, J.; Liu, Y.; Cui, J.; Jiang, Y. Branched rolling circle amplification method for measuring serum circulating microRNA levels for early breast cancer detection. Cancer Sci. 2018, 109, 2897-2906. [CrossRef]

41. Heneghan, H.M.; Miller, N.; Kelly, R.; Newell, J.; Kerin, M.J. Systemic miRNA-195 Differentiates Breast Cancer from Other Malignancies and Is a Potential Biomarker for Detecting Noninvasive and Early Stage Disease. Oncologist 2010, 15, 673-682. [CrossRef]

42. McDermott, A.M.; Miller, N.; Wall, D.; Martyn, L.M.; Ball, G.; Sweeney, K.J.; Kerin, M.J. Identification and validation of oncologic miRNA biomarkers for luminal A-like breast cancer. PLoS ONE 2014, 9, e87032. [CrossRef] [PubMed]

43. Kodahl, A.R.; Zeuthen, P.; Binder, H.; Knoop, A.S.; Ditzel, H.J. Alterations in Circulating miRNA Levels following Early-Stage Estrogen Receptor-Positive Breast Cancer Resection in Post-Menopausal Women. PLoS ONE 2014, 9. [CrossRef]

44. Guo, H.; Zeng, X.; Li, H.; Guo, Y.; Wang, T.; Guo, H.; Zhu, G.; Wang, L.; Zhou, H.; Liu, K.; et al. Plasma miR-1273g-3p acts as a potential biomarker for early Breast Ductal Cancer diagnosis. An. Acad. Bras. Cienc. 2020, 92, e20181203. [CrossRef]

45. McAnena, P.; Tanriverdi, K.; Curran, C.; Gilligan, K.; Freedman, J.E.; Brown, J.A.L.; Kerin, M.J. Circulating microRNAs miR-331 and miR-195 differentiate local luminal a from metastatic breast cancer. BMC Cancer 2019, 19, 436. [CrossRef] 
46. Wanandi, S.I.; Syahrani, R.A.; Arumsari, S.; Wideani, G.; Hardiany, N.S. Profiling of Gene Expression Associated with Stemness and Aggressiveness of ALDH1A1-Expressing Human Breast Cancer Cells. Malays. J. Med. Sci. 2019, 26, 38-52. [CrossRef]

47. Holliday, D.L.; Speirs, V. Choosing the right cell line for breast cancer research. Breast Cancer Res. 2011, 13, 215. [CrossRef] [PubMed]

48. Guttilla, I.K.; Adams, B.D.; White, B.A. ER $\alpha$, microRNAs, and the epithelial-mesenchymal transition in breast cancer. Trends Endocrinol. Metab. 2012, 23, 73-82. [CrossRef]

49. Lin, J.; Wang, L.; Gao, J.; Zhu, S. MiR-203 inhibits estrogen-induced viability, migration and invasion of estrogen receptor $\alpha$-positive breast cancer cells. Exp. Ther. Med. 2017, 14, 2702-2708. [CrossRef]

50. Rennebeck, G.; Martelli, M.; Kyprianou, N. Anoikis and Survival Connections in the Tumor Microenvironment: Is There a Role in Prostate Cancer Metastasis? Cancer Res. 2005, 65, 11230-11235. [CrossRef] [PubMed]

51. Malagobadan, S.; Ho, C.S.; Nagoor, N.H. MicroRNA-6744-5p promotes anoikis in breast cancer and directly targets NAT1 enzyme. Cancer Biol. Med. 2020, 17, 101-111. [CrossRef]

52. Van Zijl, F.; Krupitza, G.; Mikulits, W. Initial steps of metastasis: Cell invasion and endothelial transmigration. Mutat. Res. 2011, 728, 23-34. [CrossRef] [PubMed]

53. Zeng, Z.; Yang, Y.; Wu, H. MicroRNA-765 alleviates the malignant progression of breast cancer via interacting with EZH1. Am. J. Transl. Res. 2019, 11, 4500-4507.

54. Lin, C.; Gao, B.; Yan, X.; Lei, Z.; Chen, K.; Li, Y.; Zeng, Q.; Chen, Z.; Li, H. MicroRNA 628 suppresses migration and invasion of breast cancer stem cells through targeting SOS1. Onco Targets Ther. 2018, 11, 5419-5428. [CrossRef]

55. Yu, C.; Wang, Y.; Peng, J.; Shen, Q.; Chen, M.; Tang, W.; Li, X.; Cai, C.; Wang, B.; Cai, S.; et al. Mitochondrial calcium uniporter as a target of microRNA-340 and promoter of metastasis via enhancing the Warburg effect. Oncotarget 2017, 8, 83831-83844. [CrossRef]

56. Rahimi, M.; Sharifi-Zarchi, A.; Zarghami, N.; Geranpayeh, L.; Ebrahimi, M.; Alizadeh, E. Down-Regulation of miR-200c and Up-Regulation of miR-30c Target both Stemness and Metastasis Genes in Breast Cancer. Cell J. 2020, 21, 467-478. [CrossRef] [PubMed]

57. Örs Kumoğlu, G.; Döşkaya, M.; Gulce Iz, S. The biomarker features of miR-145-3p determined via meta-analysis validated by qRT-PCR in metastatic cancer cell lines. Gene 2019, 710, 341-353. [CrossRef]

58. Tang, C.-P.; Zhou, H.-J.; Qin, J.; Luo, Y.; Zhang, T. MicroRNA-520c-3p negatively regulates EMT by targeting IL-8 to suppress the invasion and migration of breast cancer. Oncol. Rep. 2017, 38, 3144-3152. [CrossRef]

59. Yin, K.; Yin, W.; Wang, Y.; Zhou, L.; Liu, Y.; Yang, G.; Wang, J.; Lu, J. MiR-206 suppresses epithelial mesenchymal transition by targeting TGF- $\beta$ signaling in estrogen receptor positive breast cancer cells. Oncotarget 2016, 7, 24537-24548. [CrossRef]

60. Sun, G.; Liu, M.; Han, H. Overexpression of microRNA-190 inhibits migration, invasion, epithelial-mesenchymal transition, and angiogenesis through suppression of protein kinase B-extracellular signal-regulated kinase signaling pathway via binding to stanniocalicin 2 in breast cancer. J. Cell. Physiol. 2019, 234, 17824-17838. [CrossRef]

61. Zhou, X.; Wang, X.; Huang, Z.; Xu, L.; Zhu, W.; Liu, P. An ER-associated miRNA signature predicts prognosis in ER-positive breast cancer. J. Exp. Clin. Cancer Res. 2014, 33, 94. [CrossRef] [PubMed]

62. Amorim, M.; Lobo, J.; Fontes-Sousa, M.; Estevão-Pereira, H.; Salta, S.; Lopes, P.; Coimbra, N.; Antunes, L.; Palma de Sousa, S.; Henrique, R.; et al. Predictive and Prognostic Value of Selected MicroRNAs in Luminal Breast Cancer. Front. Genet. 2019, 10. [CrossRef]

63. Sevinc, E.D.; Egeli, U.; Cecener, G.; Tezcan, G.; Tunca, B.; Gokgoz, S.; Tasdelen, I.; Tolunay, S.; Evrensel, T. Association of miR-1266 with recurrence/metastasis potential in estrogen receptor positive breast cancer patients. Asian Pac. J. Cancer Prev. 2015, 16, 291-297. [CrossRef] [PubMed]

64. Zhang, Z.; Xu, L.; He, L.; Wang, J.; Shi, X.; Li, Z.; Shi, S.; Hou, K.; Teng, Y.; Qu, X. MiR-891a-5p as a prognostic marker and therapeutic target for hormone receptor-positive breast cancer. J. Cancer 2020, 11, 3771-3782. [CrossRef]

65. Emmadi, R.; Canestrari, E.; Arbieva, Z.H.; Mu, W.; Dai, Y.; Frasor, J.; Wiley, E. Correlative Analysis of miRNA Expression and Oncotype Dx Recurrence Score in Estrogen Receptor Positive Breast Carcinomas. PLoS ONE 2015, 10, e0145346. [CrossRef] 
66. Milevskiy, M.J.G.; Gujral, U.; Del Lama Marques, C.; Stone, A.; Northwood, K.; Burke, L.J.; Gee, J.M.W.; Nephew, K.; Clark, S.; Brown, M.A. MicroRNA-196a is regulated by ER and is a prognostic biomarker in ER+ breast cancer. Br. J. Cancer 2019, 120, 621-632. [CrossRef]

67. Sahlberg, K.K.; Bottai, G.; Naume, B.; Burwinkel, B.; Calin, G.A.; Børresen-Dale, A.-L.; Santarpia, L. A Serum MicroRNA Signature Predicts Tumor Relapse and Survival in Triple-Negative Breast Cancer Patients. Clin. Cancer Res. 2015, 21, 1207-1214. [CrossRef] [PubMed]

68. Chen, Z.; Zhan, Y.; Chi, J.; Guo, S.; Zhong, X.; He, A.; Zheng, J.; Gong, Y.; Li, X.; Zhou, L. Using microRNAs as Novel Predictors of Urologic Cancer Survival: An Integrated Analysis. EBioMedicine 2018, 34, 94-107. [CrossRef]

69. Aure, M.R.; Vitelli, V.; Jernström, S.; Kumar, S.; Krohn, M.; Due, E.U.; Haukaas, T.H.; Leivonen, S.-K.; Vollan, H.K.M.; Lüders, T.; et al. Integrative clustering reveals a novel split in the luminal A subtype of breast cancer with impact on outcome. Breast Cancer Res. 2017, 19, 44. [CrossRef]

70. Wang, J.; Zhao, J.; Shi, M.; Ding, Y.; Sun, H.; Yuan, F.; Zou, Z. Elevated Expression of miR-210 Predicts Poor Survival of Cancer Patients: A Systematic Review and Meta-Analysis. PLoS ONE 2014, 9, e89223. [CrossRef]

71. Qin, Q.; Furong, W.; Baosheng, L. Multiple functions of hypoxia-regulated miR-210 in cancer. J. Exp. Clin. Cancer Res. 2014, 33, 50. [CrossRef] [PubMed]

72. Zhou, X.; Marian, C.; Makambi, K.H.; Kosti, O.; Kallakury, B.V.S.; Loffredo, C.A.; Zheng, Y.-L. MicroRNA-9 as potential biomarker for breast cancer local recurrence and tumor estrogen receptor status. PLOS ONE 2012, 7, e39011. [CrossRef]

73. Wang, J.; Zhao, H.; Tang, D.; Wu, J.; Yao, G.; Zhang, Q. Overexpressions of MicroRNA-9 and MicroRNA-200c in Human Breast Cancers Are Associated with Lymph Node Metastasis. Cancer Biother. Radiopharm. 2013, 28, 283-288. [CrossRef]

74. Hoppe, R.; Achinger-Kawecka, J.; Winter, S.; Fritz, P.; Lo, W.-Y.; Schroth, W.; Brauch, H. Increased expression of miR-126 and miR-10a predict prolonged relapse-free time of primary oestrogen receptor-positive breast cancer following tamoxifen treatment. Eur. J. Cancer 2013, 49, 3598-3608. [CrossRef] [PubMed]

75. Győrffy, B.; Hatzis, C.; Sanft, T.; Hofstatter, E.; Aktas, B.; Pusztai, L. Multigene prognostic tests in breast cancer: Past, present, future. Breast Cancer Res. 2015, 17. [CrossRef]

76. Aushev, V.N.; Lee, E.; Zhu, J.; Gopalakrishnan, K.; Li, Q.; Teitelbaum, S.L.; Wetmur, J.; Esposti, D.D.; Hernandez-Vargas, H.; Herceg, Z.; et al. Novel Predictors of Breast Cancer Survival Derived from miRNA Activity Analysis. Clin. Cancer Res. 2018, 24, 581-591. [CrossRef] [PubMed]

77. Lee, S.J.; Seo, J.W.; Chae, Y.S.; Kim, J.G.; Kang, B.W.; Kim, W.W.; Jung, J.H.; Park, H.Y.; Jeong, J.Y.; Park, J.-Y. Genetic polymorphism of miR-196a as a prognostic biomarker for early breast cancer. Anticancer Res. 2014, 34, 2943-2949. [PubMed]

78. Early Breast Cancer Trialists' Collaborative Group (EBCTCG); Davies, C.; Godwin, J.; Gray, R.; Clarke, M.; Cutter, D.; Darby, S.; McGale, P.; Pan, H.C.; Taylor, C.; et al. Relevance of breast cancer hormone receptors and other factors to the efficacy of adjuvant tamoxifen: Patient-level meta-analysis of randomised trials. Lancet 2011, 378, 771-784. [CrossRef]

79. Muluhngwi, P.; Krishna, A.; Vittitow, S.L.; Napier, J.T.; Richardson, K.M.; Ellis, M.; Mott, J.L.; Klinge, C.M. Tamoxifen differentially regulates miR-29b-1 and miR-29a expression depending on endocrine-sensitivity in breast cancer cells. Cancer Lett. 2017, 388, 230-238. [CrossRef]

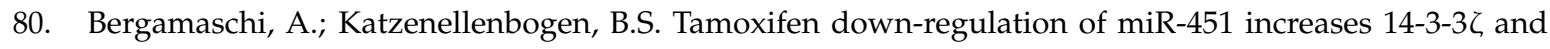
promotes breast cancer cell survival and endocrine resistance. Oncogene 2012, 31, 39-47. [CrossRef]

81. Cardoso, F.; Costa, A.; Senkus, E.; Aapro, M.; André, F.; Barrios, C.H.; Bergh, J.; Bhattacharyya, G.; Biganzoli, L.; Cardoso, M.J.; et al. 3rd ESO-ESMO international consensus guidelines for Advanced Breast Cancer (ABC 3). Breast 2017, 31, 244-259. [CrossRef]

82. Sadat Alamolhodaei, N.; Behravan, J.; Mosaffa, F.; Karimi, G. MiR 221/222 as New Players in Tamoxifen Resistance. Curr. Pharm. Des. 2016, 22, 6946-6955. [CrossRef] [PubMed]

83. Joshi, T.; Elias, D.; Stenvang, J.; Alves, C.L.; Teng, F.; Lyng, M.B.; Lykkesfeldt, A.E.; Brünner, N.; Wang, J.; Gupta, R.; et al. Integrative analysis of miRNA and gene expression reveals regulatory networks in tamoxifen-resistant breast cancer. OncoTarget 2016, 7, 57239-57253. [CrossRef] [PubMed]

84. Nam, S.; Long, X.; Kwon, C.; Kim, S.; Nephew, K.P. An integrative analysis of cellular contexts, miRNAs and mRNAs reveals network clusters associated with antiestrogen-resistant breast cancer cells. BMC Genom. 2012, 13, 732. [CrossRef] [PubMed] 
85. Zhao, J.-J.; Lin, J.; Yang, H.; Kong, W.; He, L.; Ma, X.; Coppola, D.; Cheng, J.Q. MicroRNA-221/222 negatively regulates estrogen receptor $\alpha$ and is associated with tamoxifen resistance in breast cancer. J. Biol. Chem. 2016, 291, 22859. [CrossRef]

86. Miller, T.E.; Ghoshal, K.; Ramaswamy, B.; Roy, S.; Datta, J.; Shapiro, C.L.; Jacob, S.; Majumder, S. MicroRNA-221/222 confers tamoxifen resistance in breast cancer by targeting p27Kip1. J. Biol. Chem. 2008, 283, 29897-29903. [CrossRef] [PubMed]

87. Cun, J.; Yang, Q. Bioinformatics-based interaction analysis of miR-92a-3p and key genes in tamoxifen-resistant breast cancer cells. Biomed. Pharmacother. 2018, 107, 117-128. [CrossRef]

88. Li, J.; Lu, M.; Jin, J.; Lu, X.; Xu, T.; Jin, S. miR-449a Suppresses Tamoxifen Resistance in Human Breast Cancer Cells by Targeting ADAM22. CPB 2018, 50, 136-149. [CrossRef] [PubMed]

89. Zhang, W.; Wu, M.; Chong, Q.-Y.; Zhang, M.; Zhang, X.; Hu, L.; Zhong, Y.; Qian, P.; Kong, X.; Tan, S.; et al. Loss of Estrogen-Regulated MIR135A1 at 3p21.1 Promotes Tamoxifen Resistance in Breast Cancer. Cancer Res. 2018, 78, 4915-4928. [CrossRef]

90. Ljepoja, B.; García-Roman, J.; Sommer, A.-K.; Wagner, E.; Roidl, A. MiRNA-27a sensitizes breast cancer cells to treatment with Selective Estrogen Receptor Modulators. Breast 2019, 43, 31-38. [CrossRef]

91. Zhang, W.; Xu, J.; Shi, Y.; Sun, Q.; Zhang, Q.; Guan, X. The novel role of miRNAs for tamoxifen resistance in human breast cancer. Cell. Mol. Life Sci. 2015, 72, 2575-2584. [CrossRef]

92. Cui, J.; Yang, Y.; Li, H.; Leng, Y.; Qian, K.; Huang, Q.; Zhang, C.; Lu, Z.; Chen, J.; Sun, T.; et al. MiR-873 regulates $\mathrm{ER} \alpha$ transcriptional activity and tamoxifen resistance via targeting CDK3 in breast cancer cells. Oncogene 2015, 34, 3895-3907. [CrossRef] [PubMed]

93. Zheng, L.; Meng, X.; Li, X.; Zhang, Y.; Li, C.; Xiang, C.; Xing, Y.; Xia, Y.; Xi, T. miR-125a-3p inhibits ER $\alpha$ transactivation and overrides tamoxifen resistance by targeting CDK3 in estrogen receptor-positive breast cancer. FASEB J. 2018, 32, 588-600. [CrossRef] [PubMed]

94. Ye, P.; Fang, C.; Zeng, H.; Shi, Y.; Pan, Z.; An, N.; He, K.; Zhang, L.; Long, X. Differential microRNA expression profiles in tamoxifen-resistant human breast cancer cell lines induced by two methods. Oncol. Lett. 2018, 15, 3532-3539. [CrossRef] [PubMed]

95. Shen, R.; Wang, Y.; Wang, C.-X.; Yin, M.; Liu, H.-L.; Chen, J.-P.; Han, J.-Q.; Wang, W.-B. miRNA-155 mediates TAM resistance by modulating SOCS6-STAT3 signalling pathway in breast cancer. Am. J. Transl. Res. 2015, 7, 2115-2126.

96. Kim, Y.S.; Park, S.J.; Lee, Y.S.; Kong, H.K.; Park, J.H. miRNAs involved in LY6K and estrogen receptor $\alpha$ contribute to tamoxifen-susceptibility in breast cancer. Oncotarget 2016, 7, 42261-42273. [CrossRef]

97. Yu, X.; Luo, A.; Liu, Y.; Wang, S.; Li, Y.; Shi, W.; Liu, Z.; Qu, X. MiR-214 increases the sensitivity of breast cancer cells to tamoxifen and fulvestrant through inhibition of autophagy. Mol. Cancer 2015, 14. [CrossRef]

98. He, M.; Jin, Q.; Chen, C.; Liu, Y.; Ye, X.; Jiang, Y.; Ji, F.; Qian, H.; Gan, D.; Yue, S.; et al. The miR-186-3p/ EREG axis orchestrates tamoxifen resistance and aerobic glycolysis in breast cancer cells. Oncogene 2019, 38, 5551-5565. [CrossRef]

99. Liu, J.; Li, X.; Wang, M.; Xiao, G.; Yang, G.; Wang, H.; Li, Y.; Sun, X.; Qin, S.; Du, N.; et al. A miR-26a/E2F7 feedback loop contributes to tamoxifen resistance in ER-positive breast cancer. Int. J. Oncol. 2018, 53, 1601-1612. [CrossRef]

100. Zhu, J.; Zou, Z.; Nie, P.; Kou, X.; Wu, B.; Wang, S.; Song, Z.; He, J. Downregulation of microRNA-27b-3p enhances tamoxifen resistance in breast cancer by increasing NR5A2 and CREB1 expression. Cell Death Dis. 2016, 7, e2454. [CrossRef]

101. Ikeda, K.; Horie-Inoue, K.; Ueno, T.; Suzuki, T.; Sato, W.; Shigekawa, T.; Osaki, A.; Saeki, T.; Berezikov, E.; Mano, H.; et al. miR-378a-3p modulates tamoxifen sensitivity in breast cancer MCF-7 cells through targeting GOLT1A. Sci. Rep. 2015, 5, 13170. [CrossRef]

102. Ahmad, A.; Ginnebaugh, K.R.; Yin, S.; Bollig-Fischer, A.; Reddy, K.B.; Sarkar, F.H. Functional role of miR-10b in tamoxifen resistance of ER-positive breast cancer cells through down-regulation of HDAC4. BMC Cancer 2015, 15. [CrossRef] [PubMed]

103. Luengo-Gil, G.; García-Martínez, E.; Chaves-Benito, A.; Conesa-Zamora, P.; Navarro-Manzano, E.; González-Billalabeitia, E.; García-Garre, E.; Martínez-Carrasco, A.; Vicente, V.; Ayala de la Peña, F. Clinical and biological impact of miR-18a expression in breast cancer after neoadjuvant chemotherapy. Cell Oncol. 2019, 42, 627-644. [CrossRef] [PubMed] 
104. Lu, Y.; Roy, S.; Nuovo, G.; Ramaswamy, B.; Miller, T.; Shapiro, C.; Jacob, S.T.; Majumder, S. Anti-microRNA-222 (anti-miR-222) and -181B suppresses growth of tamoxifen-resistant xenografts in mouse by targeting TIMP3 protein and modulating mitogenic signal. J. Biol. Chem. 2018, 293, 3588. [CrossRef]

105. Song, B.; Wang, C.; Liu, J.; Wang, X.; Lv, L.; Wei, L.; Xie, L.; Zheng, Y.; Song, X. MicroRNA-21 regulates breast cancer invasion partly by targeting tissue inhibitor of metalloproteinase 3 expression. J. Exp. Clin. Cancer Res. 2010, 29, 29. [CrossRef]

106. Hafez, M.M.; Hassan, Z.K.; Zekri, A.R.N.; Gaber, A.A.; Al Rejaie, S.S.; Sayed-Ahmed, M.M.; Al Shabanah, O. MicroRNAs and metastasis-related gene expression in Egyptian breast cancer patients. Asian Pac. J. Cancer Prev. 2012, 13, 591-598. [CrossRef] [PubMed]

107. Wei, Y.; Lai, X.; Yu, S.; Chen, S.; Ma, Y.; Zhang, Y.; Li, H.; Zhu, X.; Yao, L.; Zhang, J. Exosomal miR-221/222 enhances tamoxifen resistance in recipient ER-positive breast cancer cells. Breast Cancer Res. Treat. 2014, 147, 423-431. [CrossRef] [PubMed]

108. Martin, E.C.; Conger, A.K.; Yan, T.J.; Hoang, V.T.; Miller, D.F.B.; Buechlein, A.; Rusch, D.B.; Nephew, K.P.; Collins-Burow, B.M.; Burow, M.E. MicroRNA-335-5p and -3p synergize to inhibit estrogen receptor alpha expression and promote tamoxifen resistance. FEBS Lett. 2017, 591, 382-392. [CrossRef]

109. Ward, A.; Shukla, K.; Balwierz, A.; Soons, Z.; König, R.; Sahin, Ö.; Wiemann, S. MicroRNA-519a is a novel oncomir conferring tamoxifen resistance by targeting a network of tumour-suppressor genes in ER+ breast cancer. J. Pathol. 2014, 233, 368-379. [CrossRef] [PubMed]

110. Jiang, H.; Cheng, L.; Hu, P.; Liu, R. MicroRNA-663b mediates TAM resistance in breast cancer by modulating TP73 expression. Mol. Med. Rep. 2018, 18, 1120-1126. [CrossRef]

111. Shi, W.; Gerster, K.; Alajez, N.M.; Tsang, J.; Waldron, L.; Pintilie, M.; Hui, A.B.Y.; Sykes, J.; P'ng, C.; Miller, N.; et al. MicroRNA-301 Mediates Proliferation and Invasion in Human Breast Cancer. Cancer Res. 2011. [CrossRef]

112. Chen, M.-J.; Cheng, Y.-M.; Chen, C.-C.; Chen, Y.-C.; Shen, C.-J. MiR-148a and miR-152 reduce tamoxifen resistance in ER+ breast cancer via downregulating ALCAM. Biochem. Biophys. Res. Commun. 2017, 483, 840-846. [CrossRef] [PubMed]

113. Manavalan, T.T.; Teng, Y.; Litchfield, L.M.; Muluhngwi, P.; Al-Rayyan, N.; Klinge, C.M. Reduced Expression of miR-200 Family Members Contributes to Antiestrogen Resistance in LY2 Human Breast Cancer Cells. PLoS ONE 2013, 8, e62334. [CrossRef] [PubMed]

114. Gao, Y.; Zhang, W.; Liu, C.; Li, G. miR-200 affects tamoxifen resistance in breast cancer cells through regulation of MYB. Sci. Rep. 2019, 9, 18844. [CrossRef]

115. Hrstka, R.; Nenutil, R.; Fourtouna, A.; Maslon, M.M.; Naughton, C.; Langdon, S.; Murray, E.; Larionov, A.; Petrakova, K.; Muller, P.; et al. The pro-metastatic protein anterior gradient-2 predicts poor prognosis in tamoxifen-treated breast cancers. Oncogene 2010, 29, 4838-4847. [CrossRef] [PubMed]

116. Achari, C.; Winslow, S.; Ceder, Y.; Larsson, C. Expression of miR-34c induces G2/M cell cycle arrest in breast cancer cells. BMC Cancer 2014, 14, 538. [CrossRef]

117. Antonini, D.; Russo, M.T.; De Rosa, L.; Gorrese, M.; Del Vecchio, L.; Missero, C. Transcriptional Repression of miR-34 Family Contributes to p63-Mediated Cell Cycle Progression in Epidermal Cells. J. Investig. Dermatol. 2010, 130, 1249-1257. [CrossRef]

118. Wei, J.; Shi, Y.; Zheng, L.; Zhou, B.; Inose, H.; Wang, J.; Guo, X.E.; Grosschedl, R.; Karsenty, G. miR-34s inhibit osteoblast proliferation and differentiation in the mouse by targeting SATB2. J. Cell Biol. 2012, 197, 509-521. [CrossRef]

119. Ward, A.; Balwierz, A.; Zhang, J.D.; Küblbeck, M.; Pawitan, Y.; Hielscher, T.; Wiemann, S.; Sahin, Ö. Re-expression of microRNA-375 reverses both tamoxifen resistance and accompanying EMT-like properties in breast cancer. Oncogene 2013, 32, 1173-1182. [CrossRef]

120. Zhou, Q.; Zeng, H.; Ye, P.; Shi, Y.; Guo, J.; Long, X. Differential microRNA profiles between fulvestrant-resistant and tamoxifen-resistant human breast cancer cells. Anticancer Drugs 2018, 29, 539-548. [CrossRef]

121. Tangkeangsirisin, W.; Serrero, G. GP88 (Progranulin) Confers Fulvestrant (Faslodex, ICI 182,780) Resistance to Human Breast Cancer Cells. Adv. Breast Cancer Res. 2014, 3, 68-78. [CrossRef]

122. Tsuboi, K.; Kaneko, Y.; Nagatomo, T.; Fujii, R.; Hanamura, T.; Gohno, T.; Yamaguchi, Y.; Niwa, T.; Hayashi, S.-I. Different epigenetic mechanisms of ER $\alpha$ implicated in the fate of fulvestrant-resistant breast cancer. J. Steroid Biochem. Mol. Biol. 2017, 167, 115-125. [CrossRef] 
123. Rao, X.; Di Leva, G.; Li, M.; Fang, F.; Devlin, C.; Hartman-Frey, C.; Burow, M.E.; Ivan, M.; Croce, C.M.; Nephew, K.P. MicroRNA-221/222 confers breast cancer fulvestrant resistance by regulating multiple signaling pathways. Oncogene 2011, 30, 1082-1097. [CrossRef]

124. Fan, M.; Yan, P.S.; Hartman-Frey, C.; Chen, L.; Paik, H.; Oyer, S.L.; Salisbury, J.D.; Cheng, A.S.L.; Li, L.; Abbosh, P.H.; et al. Diverse gene expression and DNA methylation profiles correlate with differential adaptation of breast cancer cells to the antiestrogens tamoxifen and fulvestrant. Cancer Res. 2006, 66, 11954-11966. [CrossRef] [PubMed]

125. Xin, F.; Li, M.; Balch, C.; Thomson, M.; Fan, M.; Liu, Y.; Hammond, S.M.; Kim, S.; Nephew, K.P. Computational analysis of microRNA profiles and their target genes suggests significant involvement in breast cancer antiestrogen resistance. Bioinformatics 2009, 25, 430-434. [CrossRef] [PubMed]

126. Guo, J.; He, K.; Zeng, H.; Shi, Y.; Ye, P.; Zhou, Q.; Pan, Z.; Long, X. Differential microRNA expression profiles determined by next-generation sequencing in three fulvestrant-resistant human breast cancer cell lines. Oncol. Lett. 2019, 17, 3765-3776. [CrossRef]

127. Vilquin, P.; Donini, C.F.; Villedieu, M.; Grisard, E.; Corbo, L.; Bachelot, T.; Vendrell, J.A.; Cohen, P.A. MicroRNA-125b upregulation confers aromatase inhibitor resistance and is a novel marker of poor prognosis in breast cancer. Breast Cancer Res. 2015, 17. [CrossRef]

128. Bacci, M.; Giannoni, E.; Fearns, A.; Ribas, R.; Gao, Q.; Taddei, M.L.; Pintus, G.; Dowsett, M.; Isacke, C.M.; Martin, L.-A.; et al. miR-155 Drives Metabolic Reprogramming of ER+ Breast Cancer Cells Following Long-Term Estrogen Deprivation and Predicts Clinical Response to Aromatase Inhibitors. Cancer Res. 2016, 76, 1615-1626. [CrossRef]

129. Masri, S.; Liu, Z.; Phung, S.; Wang, E.; Yuan, Y.-C.; Chen, S. The role of microRNA-128a in regulating TGFbeta signaling in letrozole-resistant breast cancer cells. Breast Cancer Res Treat 2010, 124, 89-99. [CrossRef] [PubMed]

130. Hoppe, R.; Fan, P.; Büttner, F.; Winter, S.; Tyagi, A.K.; Cunliffe, H.; Jordan, V.C.; Brauch, H. Profiles of miRNAs matched to biology in aromatase inhibitor resistant breast cancer. Oncotarget 2016, 7, 71235-71254. [CrossRef]

131. Citron, F.; Segatto, I.; Vinciguerra, G.L.R.; Musco, L.; Russo, F.; Mungo, G.; D'Andrea, S.; Mattevi, M.C.; Perin, T.; Schiappacassi, M.; et al. Downregulation of miR-223 expression is an early event during mammary transformation and confers resistance to CDK4/6 inhibitors in luminal breast cancer. Cancer Res. 2019. [CrossRef]

Publisher's Note: MDPI stays neutral with regard to jurisdictional claims in published maps and institutional affiliations.

(C) 2020 by the authors. Licensee MDPI, Basel, Switzerland. This article is an open access article distributed under the terms and conditions of the Creative Commons Attribution (CC BY) license (http://creativecommons.org/licenses/by/4.0/). 